\title{
Zniszczenie ziemi w Księdze Judyty jako sposób wystąpienia szatana przeciwko Bogu
}

\section{Wprowadzenie}

W Księdze Judyty przekazana została niezwykła i trudna do wyjaśnienia wypowiedź króla Nabuchodonozora, który „(...) zapowiedział ustami swoimi zupełną zagładę całej ziemi" (Jdt 2,2b) ${ }^{1}$. O absurdalności tej wypowiedzi odczytanej w sensie dosłownym można wnioskować na podstawie wielu przesłanek. Z kontekstu wynika, że jedynym możliwym do przyjęcia motywem działania władcy jest zemsta nad przeciwnikami, którzy nie chcieli poddać się jego władzy. Jednak nietrudno zauważyć, iż przy dosłownym potraktowaniu zapowiedzi monarchy ofiarami jego działań musieliby zostać także ci, którzy deklarowali lojalność wobec niego. Motywem prowadzenia wojny mogłaby być także demonstracja siły, jednak wydaje się ona całkowicie zbyteczna w kontekście zwycięstwa odniesionego nad Arfaksadem, opisanego w rozdziale pierwszym. Ponadto demonstracja siły nabiera sensu w przypadku gdy jest środkiem do osiągnięcia celu, zaś sama w sobie nie stanowi raczej przekonującej motywacji działania. Po realizacji królewskiej zapowiedzi i zniszczeniu wszelkiego życia nie było by komu drżeć przed jego potęgą. Wreszcie należy zauważyć, że totalne zniszczenie wiąże się także z pozbawieniem zwycięskiej armii łupów wojennych, które stanowiły przecież ważny element motywujący żołnierzy do walki.

Rozwiązania problemu można szukać przy wykorzystaniu różnorakich metod egzegetycznych, zarówno synchronicznych jak i diachronicznych, jak również przez ustalenie sensu tekstu poddawanego analizie przy uwzględnieniu hermeneutycznych reguł noematycznych. Niniejszy tekst jest zatem próbą wyjaśnienia zamiarów króla jako alegorii oczekiwań szatana, zamierzającego zniszczyć stworzenie w celu wystąpienia przeciwko Stwórcy.

\footnotetext{
1 Wszystkie cytaty i sigla biblijne użyte w niniejszym opracowaniu pochodzą z Biblii Tysiąclecia.
} 


\section{Irrealizm Księgi Judyty}

Księga Judyty, należąca do pism deuterokanonicznych Starego Testamentu², powstała prawdopodobnie $\mathrm{w}$ drugim wieku przed $\mathrm{Chr}^{3}$. W tym czasie Izraelici doświadczali gwałtownego konfliktu pomiędzy judaizmem i hellenizmem ${ }^{4}$. Front tej walki nie przebiegał jednak zgodnie z podziałem etnicznym, gdyż także wielu Żydów należało do zwolenników hellenizacji. Powstanie machabejskie, które było reakcją na terror wprowadzony przez Antiocha IV, miało u swoich podstaw troskę o obronę wiary wobec bezbożnych praktyk narzucanych przez władcę. Nieznany $z$ imienia autor Księgi Judyty znajdował się zapewne w centrum wydarzeń. Ze względu na doskonałą orientację $w$ problematyce religijno - kultycznej oraz znajomość świątyni jerozolimskiej przypuszcza się, że był on mieszkańcem Palestyny a nie diaspory ${ }^{5}$.

W świetle powyższych informacji bardzo zastanawiające wydaje się przedstawienie w księdze wydarzeń budzących wiele zastrzeżeń $\mathrm{w}$ zestawieniu z faktami znanymi z historii powszechnej ${ }^{6}$. Nabuchodonozor nazywany jest królem Asyrii (por. Jdt 1,1 ), podczas gdy faktycznie był on władcą państwa neobabilońskiego, należącym do dynastii chaldejskiej. Stolicę kraju autor natchniony umieszcza w Niniwie, która zburzona została w 612 r. przed Chr., a więc kilka lat przed objęciem władzy przez znanego z historii, a także z Biblii (por. Księga Daniela), króla Nabuchodonozora. Tymczasem faktyczną stolicą Nabuchodonozora było

2 Tekst Księgi znany jest współcześnie jedynie z LXX, jednak istnieje uzasadnione przypuszczenie, że oryginał został spisany w języku hebrajskim lub aramejskim. Por. E. ZENGER, Das Buch Judith, Gütersloh 1981, 430. Hipoteza ta opiera się m.in. na świadectwie Hieronima, który przy tworzeniu Wulgaty miał korzystać $z$ tekstu aramejskiego. Por. Hieronim, Praefatio in Judith, PL 29, 37-40. Jednak żaden taki tekst nie został dotychczas odnaleziony. Por. R. RajA, Księga Judyty, th. P. PACHCIAREK, w: Międzynarodowy komentarz do Pisma Świętego, red. W. Farmer, red. wyd. polskiego W. Chrostowski, Warszawa 2001, 600.

3 Por. U. Szwarc, Judyty Księga, w: Encyklopedia katolicka, t.8, Lublin 2000, 221.

4 Hellenizm jest formą kulturową, powstałą w wyniku zdobywczych wojen Aleksandra Macedońskiego i wzajemnego oddziaływania na siebie kultury greckiej i orientalnej. Niektórzy proponują zawężenie rozumienia tego pojęcia do greckiej historii (lub ewentualnie historii kultury greckiej) w okresie od Aleksandra Wielkiego do cesarza Augusta Por. W. Kopaliński, Stownik mitów i tradycji kultury, Warszawa 1987, 367. Terminu tego użył po raz pierwszy niemiecki historyk J. G. Droysen w 1836r. Por. M. Rusecki, Hellenizm, w: Encyklopedia Katolicka t. 6, Lublin 1993, 660. Narzędziem rozpowszechnienia hellenizmu był język grecki, a szczególnie jego odmiana - koine, stanowiąca w swoim czasie lingua franca cywilizowanego świata.

5 Por. S. Synowiec, Mędrcy Izraela ich pisma i nauka, Kraków 1997, 239.

6 Księga Judyty w podziale chrześcijańskim umieszczona została w grupie ksiąg historycznych Starego Testamentu. Z uwagi na dość specyficzne podejście autora do historii Księga ta podobnie jak Księgi Tobiasza i Estery określana bywa mianem literatury historyczno - mądrościowej. Układ kanonu chrześcijanskiego mimo, że wskazuje na drogę rozwoju Objawienia, ma jednak przede wszystkim charakter formalny. Por. A. PACioreK, Wstęp ogólny do Pisma Świętego, Tarnów 2003, 14-16. 
ogromne, liczące ponad pół miliona mieszkańców miasto Babilon ${ }^{7}$. Z kolei król Arfaksad nie jest wzmiankowany $w$ żadnych dokumentach $z$ epoki ${ }^{8}$. Stolica Arfaksada - Ekbatana jest wprawdzie miastem znanym $\mathrm{z}$ historii starożytnego Wschodu, jednak jej podboju w połowie szóstego wieku przed Chr. dokonał król perski Cyrus Wielki ${ }^{9}$ a nie Nabuchodonozor jak wynika z Księgi Judyty. Podobnie nieznani z innych źródeł historycznych są bohaterowie Księgi: Judyta ${ }^{10}$, Holofernes czy Achior.

Wiele wątpliwości dotyczy także realiów geograficznych prezentowanych w Księdze Judyty. Miejsce kulminacyjne narracji Księgi - Betulia nie jest znane $\mathrm{z}$ innych źródeł i nie zostało powiązane $\mathrm{z}$ żadnym miejscem na terenie Izraela ${ }^{11}$. Podobnie nieznane są wzmiankowane w Księdze (por. Jdt 4,4): Kona, Belmain, Choba, Esora i dolina Salem ${ }^{12}$.

Innym obszarem zawierającym dane trudne do zaakceptowania są opisy działań wojennych. Liczebność wojsk asyryjskich została ewidentnie wyolbrzymiona. Trasy przemarszu oraz czas przemieszczania się wojsk wydaje się całkowicie nierealny (np. przebycie przez ogromną armię siedmiuset pięćdziesięciu kilometrów w ciągu trzech dni por. Jdt 2,21).

Tak znaczne rozbieżności nie mogą być uznane za pomyłkę autora natchnionego, gdyż ich skala jest zbyt wielka a jednocześnie dotyczą wydarzeń niezwykle żywych w świadomości zbiorowej Izraela (jak niewola babilońska). Należy zatem stwierdzić, że opis wydarzeń przedstawiony w Księdze Judyty został przez autora natchnionego celowo odrealniony. Taki zabieg literacki wpisuje się w widoczny w tekście zamysł, aby stworzyć dzieło pokazujące w sposób wyraźny wielkość Boga i Jego opiekę nad Narodem Wybranym.

\section{Konstrukcja literacka Księgi}

Wydaje się, że droga do odczytania rzeczywistego przesłania Księgi prowadzi przez ustalenie jej konstrukcji literackiej. Gatunek literacki Księgi Judyty jest

7 Por. M. Jaczynowska, A. Mączkowa, W. Tyloch, Historia starożytna, Warszawa 1974, 46.

8 Por. R. RAJA, dz.cyt., 598. W Rdz 10,22 wspomniane jest imię Arpakszada, który był synem Sema. Istnieje przypuszczenie, że stanowi on symbol, któregoś spośród ludów semickich, być może Chaldejczyków. Por. C. Gordis, Arpachshad, w: The Interpreter's Dictionary of the Bible, red. G. ButTRICK, New York 1961, 231.

9 Por. R. RAJA, dz.cyt., 598.

10 Imię Judyta oznacza Żydówka. Taka etymologia pozwala wysunąć wniosek, że jest ona ucieleśnieniem pozytywnych cech, które powinna posiadać niewiasta izraelska. Por. U. Szwarc, Judyta, w: Encyklopedia katolicka, t.8, Lublin 2000, 218. Była córką Merariego z pokolenia Symeona. Por. Jdt 8,1;9,2.

11 Por.E. Saunders, Betulia, w: The Interpreter's Dictionary of the Bible, red. G. Buttrick, New York 1961, 403.

12 Por. R. RajA, dz.cyt., 598. 
przedmiotem dyskusji. Wysuwano przypuszczenia, że jest to powieść religijna ${ }^{13}$ lub też alegoryczne widowisko pasyjne ${ }^{14}$. Najwięcej zwolenników zyskała jednak teza, że Księga ta pod względem literackim stanowi midrasz haggadyczny ${ }^{15}$. Mniejszymi jednostkami literackimi, osadzonymi w tekście Księgi, są: hymny, modlitwy i mowy.

Przy odczytaniu Księgi jako haggady należy powiązać jej poszczególne elementy (postaci i wydarzenia) z wcześniejszymi tekstami biblijnymi. Zatem punktem wyjścia refleksji zawartej w Księdze Judyty są czyny różnych postaci przedstawionych w Tanach. Wyraźnie widoczna w Księdze Judyty jest aktualizacja wydarzeń paschalnych. Każde uwolnienie w interpretacji judaistycznej nawiązywało do wydarzenia Wyjścia, które to stanowiło typ wszelkiej pozytywnej transgresji. Nawiązanie to jest szczególnie widoczne w zestawieniu Pieśni Judyty (Jdt 15,14-16,14) z Pieśnią dziękczynną (Wj 15,1-21). Pokonanie Holofernesa przez słabą kobietę Judytę to reinterpretacja zwycięstwa odniesionego przez Dawida nad potężnym Goliatem. Śmierć Holofernesa to powtórne odczytanie śmierci Eglona (por. $S d z$ 3,12-30) albo Sisery (Sdz 5). Wreszcie cecha przebiegłości posiadana przez Judytę to reminiscencja opowiadań o Rebece ( $\mathrm{Rdz} 27)$, Tamar ( $R d z 38$ ) i Abigail (1Sm 25), które w różnych okolicznościach analogicznie używały jako broni podstępu ${ }^{16}$.

Ponadto w Księdze Judyty odnaleźć można konstrukcję chiastycznąą ${ }^{17}$, kórej zastosowanie podkreśla zasadnicze przesłanie całego opowiadania. Komentatorzy wyróżniają chiazm pierwszy (Jdt 2,14 - 7,32) i drugi (Jdt 8,1-16,25). Ten układ zwraca uwagę na część centralną utworu (Jdt 10,11-13,10a), w której podkreślone jest piękno Judyty oraz jej siła pochodząca od Boga. ${ }^{18}$

13 Por. E. Zenger, Der Judithroman als Traditionalmodell des Jahweglaubens, w: Trierer Theologische Zietschrift 83 (1974), 65-80.

14 Por. przedmowa do Księgi Judyty w przekładzie Marcina Lutra z 1534 r., cyt. za: R. RAJA, dz.cyt., 598.

15 Midrasz stanowi swoisty komentarz do wcześniej powstałego tekstu biblijnego. Kiedy jest on prowadzony metodą haggadyczną stanowi szczególną usystematyzowaną refleksję nad Słowem Bożym $z$ uwzględnieniem Tradycji. Por. D. Bartoszewicz, Introdukcja biblijna, Warszawa 2007, 72. Terminem midrasz określa się współcześnie zarówno samą metodę interpretacji jak i finalny tekst będący efektem zastosowania tej metody. Por. P. AleXander, Midrasz, w: Słownik hermeneutyki biblijnej, red. R. Coggins I. HouldEN, red. wyd. polskiego W. CHRostowski, tł. B. WideA, Warszawa 2005, 573.

16 Por. S. Synowiec, dz.cyt., 239.

17 Chiazmy to szczególny rodzaj paralelizmu stosowany w piśmiennictwie semickim, w którym elementy ułożone są według schematu układającego się na kształt greckiej litery chi. Stosowanie chiazmów wskazuje na niezwykle kunsztowną budowę literacką utworu. Por. P. STĘPIEŃ, Prawo lewiratu w świetle chiastycznej struktury Pwt 25, 4-12, Warszawskie Studia Teologiczne 13 (2000), 64.

18 Por. R. RajA, dz.cyt., 598. 


\section{Infernalna denotacja postaci Nabuchodonozora}

Analiza postaci i wydarzeń opisanych w Księdze Judyty doprowadziła do wniosku, że są one jedynie kostiumem historycznym skrywającym rzeczywistych bohaterów utworu. Poznanie struktury literackiej dzieła potwierdziło to przekonanie i odsłoniło mechanizm reinterpretacji Biblii w niej samej. Należy zatem postawić pytanie o czym w swej istocie uczy Księga Judyty i kto jest jej faktycznym bohaterem?

Pierwszą kluczową postacią, która pojawia się w tekście jest król Nabuchodonozor, który jak się wydaje jest ukazany jako alegoria szatana. Ten sam sposób rozumienia dotyczyć może jego sług, zwłaszcza dowodzącego królewską armią Holofernesa. Za przyjęciem takiego rozumienia przemawia przede wszystkim skala zamierzeń króla, który ostrze swego miecza kieruje przeciwko całej ziemi. Przy uznaniu takiego kierunku interpretacji zrozumiałe stają się niejasne intecje króla, o których wspomniano we wprowadzeniu. Działanie szatana jest skierowane przeciwko wszystkim, a więc także przeciw własnym sprzymierzeńcom, kiedy nie są już oni potrzebni. Tak jak żołnierze nie mogliby liczyć na nagrodę w postaci łupów wojennych, tak również współpracownicy szatana byliby nierozsądni licząc na jego lojalność.

Celem uderzenia Nabuchodonozora jest cała ziemia a pierwszym etapem - podbój. Oznacza on przejęcie władzy i narzucenie swojego prawa. Siły króla wydają się niepokonane, w zwycięskim pochodzie zalewają całą ziemię. Jest tu widoczny kontrast $z$ obrazem tych samych wojsk uciekających po zwycięstwie Judyty. Podobnie podbój prowadzony przez szatana wydaje się niemożliwy do zatrzymania, jednak po jego pokonaniu widać, że rzekoma potęga nie przeraża, gdy jest w odwrocie. Służenie królowi przez wszystkie ludy jest zamiarem odwrócenia porządku natury, w którym stworzenie służy swojemu Stwórcy ${ }^{19}$.

Drugim etapem działań króla, stanowiącym konsekwencję pierwszego, jest ogłoszenie się Bogiem aby: „(...)wszystkie języki i ich plemiona jego uznawały za boga" (Jdt 3,8). Widoczna jest tu kolejna niezgodność z realiami historycznymi, gdyż władcy babilońscy w przeciwieństwie do późniejszych królów w epoce hellenistycznej nie domagali się dla siebie czci boskiej. W zamiarze Nabuchodonozora można za to dostrzec nawiązanie do słów węża $\mathrm{z}$ Rdz 3,5, który zachęcając ludzi do wystąpienia przeciwko Bogu roztoczył przed nimi obietnicę zrównania się ze Stwórcą.

Trzecim wreszcie elementem królewskiego planu jest zniszczenie. To zapowiedź wystąpienia przeciwko życiu. Nabuchodonozor wraz ze swoimi'sojusznikami postanowil: „zgładzić każdego żyjącego” (Jdt 2,3). Pierwszym przeciwni-

19 Por. W. Chrostowskı, Ogród Eden zapoznane świadectwo asyryjskiej diaspory, Warszawa 1996, $50 \mathrm{n}$. 
kiem szatana jest JHWH, Ten który jest, Bóg dający życie i sam będący życiem (por. Wj 3,14). Jednak rezultat bezpośredniego starcia zbuntowanego stworzenia i Stwórcy jest zupełnie oczywisty. Zatem szatan decyduje się na zniszczenie ziemi aby w ten sposób pośrednio ugodzić Boga.

Wydaje się, że uznanie króla Nabuchodonozora opisanego w Księdze Judyty za symbol szatana jest uprawnione na podstawie wewnętrznej, treściowej analizy tekstu. Wątpliwości w stosunku do takiej interpretacji pochodzić mogą $\mathrm{z}$ uwzględnienia tradycji biblijnej, w której król Nabuchodonozor pomimo zła wyrządzonemu Izraelowi (niewola babilońska, zburzenie świątyni) nie jest przedstawiany jako postać zdecydowanie negatywna ${ }^{20}$.

\section{Zniszczenie ziemi jako wystąpienie przeciwko Bogu - wnioski teologiczne}

Jak wynika z przedstawionej powyższej analizy, można przyjąć, że w aspekcie teologicznym Księga Judyty ukazuje działania przeciwko stworzeniu jako w istocie niemożliwe do zrealizowania pragnienie wystąpienia przeciwko Bogu. Jest to swoiste uderzenie zastępcze wobec niemożności zaatakowania wprost Dawcy życia. Lektura Księgi pozwala na zidentyfikowanie sposobów, stosowanych przez szatana w dążeniu do unicestwienia stworzenia.

Autor natchniony zastosował $\mathrm{w}$ opisie założeń i wykonania planu przejście od wizji ogólnej do konkretów związanych $\mathrm{z}$ realizacją. Na wyższym poziomie walka przewidziana została jako starcie Nabuchodonozora, samozwańczego boga utożsamionego z szatanem, z Bogiem JHWH. Natomiast niższy stopień konfliktu to starcie pomiędzy Holofernesem i Judytą. Obie strony czerpały moc $\mathrm{z}$ góry: Holofernes stał na czele potężnej armii swego mocodawcy, zaś Judyta przez wiarę i miłość do Boga przyjęła charyzmaty niezbędne do stawienia czoła potężnemu przeciwnikowi. Na tym właśnie niższym poziomie nastąpiło rozstrzygnięcie pojedynku. Wygrała Judyta a przegrał Holofernes, ale w istocie wygrał JHWH a przegrał Nabuchodonozor i jego zamysł zniszczenia życia. Zatem postawa obrony stworzenia, nawet na niewielką skalę, może być ważnym wkładem w ostateczne zwycięstwo życia.

${ }^{20}$ Król Nabuchodonozor jest bohaterem pierwszej, historycznej części Księgi Daniela. Odnośnie biblijnej oceny jego osoby por. D. BARToszewICz, Analiza porównawcza wspótczesnych interpretacji napisu $z$ Dn 5,25 i tłumaczenia podanego przez Daniela, w: Miłość wytrwa do końca księga pamiątkowa dla ks. Profesora Stanisława Pisarka w 50. rocznicę święceń kapłańskich i 75. rocznicę urodzin, opr. W. Chrostowski, Warszawa 2004, 71-81. 
Bardzo ważnym pojęciem występującym w tekście analizowanej Księgi jest ręka. Symbolizuje ona siłę i działanie. Nabuchodonozor zadeklarował: „Na moje życie i potęgę mojego królestwa, powiedziałem i uczynię to moją ręką" (Jdt 2,12). Zestawienie tej wypowiedzi ze słowami Boga: „Wyciągnę przeto rękę i uderzę Egipt różnymi cudami, jakich tam dokonam a wypuści was" (Wj 3,20) brzmi ironicznie w sytuacji, gdy znane jest zakończenie konfliktu. Judyta wypełniająca wolę JHWH wielokrotnie używała wyrażenia ręka kobiety (por. Jdt 8,33; 9,9-10 i in.), zwracając uwagę na słabość narzędzia wybranego przez Boga. Sytuacja wdowy w starożytnym społeczeństwie Izraelu była modelowym przykładem słabości. ${ }^{21}$. Ręka Judyty nie miała więc większej mocy niż ręka Holofernesa. Faktycznym powodem zwycięstwa Judyty była ręka Boga, potężniejsza niż ręka Nabuchodonozora. Zwycięstwo odniesione słabym narzędziem tym wyraźniej eksponuje moc tego, który wygrywa walkę.

Autor Księgi Judyty zwraca szczególną uwagę na stan moralny stron opisywanego konfliktu. Postawy przeciwnych stron zostały w tej płaszczyźnie wyraźnie skontrastowane. Judyta ukazana została jako niewiasta gorliwie przestrzegająca prawa we wszelkich jego płaszczyznach. Holofernes przeciwnie scharakteryzowany został jako lubieżny hedonista nie respektujący nawet tych norm moralnych, które wynikają z prawa naturalnego ${ }^{22}$. Jego zamiłowanie do grzechu ${ }^{23}$, bardziej niż deklaracje werbalne, jest świadectwem przynależności do stronnictwa przeciwników Boga. Moralna prawość Judyty zarówno w dziedzinie ortodoksji jak i ortopraksji jest per analogiam sposobem wyrażenia więzi ze Stwórcą.

Analiza noematyczna tekstu Księgi wychodzi poza odczytanie jej tylko w kategoriach sensu wyrazowego. Główna bohaterka może być bowiem w sensie alegorycznym uznana za typ Maryi. Takie odczytanie opiera się zarówno na paralelach treściowych, jak i Tradycji uzewnętrzniającej wiarę Kościoła. Podstawą porównania obu niewiast wydaje się posiadanie przez nie cnoty męstwa. Matka Boża jest w swoim nadprzyrodzonym macierzyństwie przekazicielką życia i jego niezłomną obrończynią. Dlatego nazywana jest zgodnie z wiarą Kościoła Opiekunką i Wspomożycielką. Jej rola okazuje szczególnie ważna gdy szatan atakuje dar życia przynależny stworzeniom. Maryja określana jest jako Judyt wojująca w Godzinkach o Niepokalanym Poczęciu Najświętszej Maryi Panny.

21 Pozbawiona opieki męża mogła oczekiwać wsparcia i pomocy od rodziny zmarłego, zwłaszcza od braci, na których spoczywał obowiązek zawarcia małżeństwa lewirackiego. Por. R. DE VAUX, Instytucje Starego Testamentu, t1. T. Brzegowy, Poznań 2004, 49.

22 Pomimo silnego zaakcentowania znaczenia sprawiedliwości legalnej zwłaszcza w sferze obrzędowo - kultycznej Księga Judyty nie afirmuje postaw ksenofobicznych. Dowodem może być postać dobrego poganina Achiora, który ze względu na swoje zasługi przyjęty został do społeczności Izraela. Ta niezgodna z żydowską ortodoksją otwartość (por. Pwt 23,3-4) spotkała się $z$ krytyką ze strony rabinów. Por. R. RaJA, dz.cyt., 600 .

${ }^{23}$ Odnośnie starotestamentalnego rozumienia grzechu por. R. RUMIANEK, Grzechy malżeńskie w Starym Testamencie, Warszawa 2001, 25-41. 


\section{Podsumowanie}

Walka opisana w Księdze Judyty nie jest konfliktem historycznym. Jest to, przedstawiona $\mathrm{w}$ wyszukanej formie literackiej, refleksja nad metodami działania szatana, przeciwnika Boga, przeciwnika człowieka a także wszelkiego życia i sposobami skutecznej obrony przed jego agresją. Działanie złego przybiera różnorodne formy. Śmiercią jest każdy grzech, który zabija w człowieku Boże życie. Grzech może wprost przybrać formę zabójstwa niewinnego człowieka. Formą służenia śmierci jest także niszczenie życia w przyrodzie.

Rozwiązanie ukazane w Księdze Judyty to obrona życia nawet w niewielkiej skali, przez słabego człowieka prowadzona ze świadomością, że jest to element większego konfliktu rozgrywającego się pomiędzy Bogiem i szatanem.

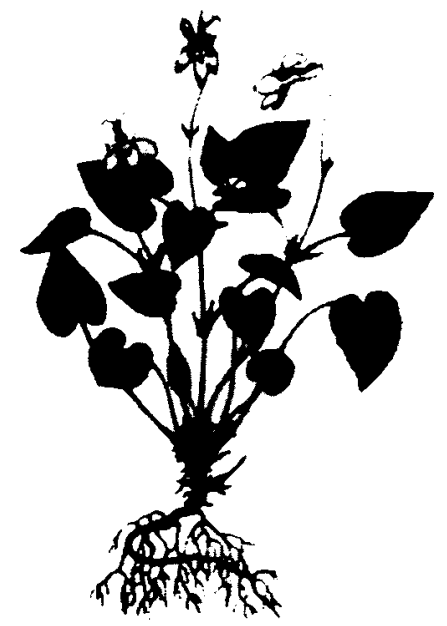

Fiolek leśny 